\title{
Islamic Communication Model in Therapeutic Communication Practices at Adam Malik Hospital
}

\author{
Syafruddin Ritonga ${ }^{1}$, Zamri $^{2}$, Selamat Riadi ${ }^{3}$, Zakaria Siregar $^{4}$ \\ ${ }^{1}$ University of Medan Area, Indonesia \\ ${ }^{2}$ Faculty of Usuluddin, Adab and Da'wah, IAIN Lhokseumawe, Indonesia \\ ${ }^{3}$ University of Sari Mutiara, Indonesia \\ ${ }^{4}$ Faculty of Social Sciences, Islamic University of North Sumatera, Indonesia \\ syafruddin@uma.ac.id
}

\section{Abstract}

Studies on Therapeutic Communication, especially its relationship to Islamic communication, are still rarely found in the field. This study aims to see how the practice of Islamic communication can be done well by doctors and nurses. This research uses a qualitative approach. The values of Islamic communication in Therapeutic communication can be seen from the way communication is carried out by doctors and nurses with their patients through ethics and good language. The implementation model of Islamic communication in therapeutic communication produces a marker communication model, that is, communication carried out on the basis of the awareness of the medical team. This communication model is not formally implemented, but in substance has similarities with the value of Islamic communication.

Keywords

Islamic communication; therapeutic communication; Medan city hospital

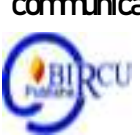

\section{Introduction}

The process of integration of studies between Islamic communications with other communications such as political communication, development communication is mostly carried out by communication scholars, this is so that the object of study can be seen from various perspectives. The problems discussed also get mixed answers.

Communication is understood as the delivery of messages (ideas / ideas, information, and invitations) to others verbally, in writing, directly and indirectly. The following is a good way to communicate according to the Koran or "Islamic Communication". The following ethics, rules, or communication principles also apply at any time and anywhere, adapted to the situation and conditions. Also applies to preachers, preachers, teachers, and every Muslim. Simply stated, communication ethics is understood as communication that puts forward communication ethics in Islam, and values that are not in conflict with the community. If related to the normative foundation of the Koran, the ethics of communication are not in conflict with the values contained in the Koran. Mainly for Muslim communicators or politicians, naturally they must prioritize and uphold the ethics of communication. Quoting Mafri Amir's explanation, that new communication is called ethical, when a communicator communicates in accordance with the standards of moral values, or the communicator communicates in accordance with the values prevailing in the community or certain groups. The value, of course, is not measured from the value of the beliefs or religion of the community itself, but is also measured from the values according to the customs (customs) that apply in the community. Therefore, to measure whether a person's communication ethics are good or not, it can be seen from the technical quality of communicating in accordance with the prevailing good values. 
Communication is the process of delivering messages by someone to other people to tell, change attitudes, opinions or behavior either directly orally or indirectly through the media. In this communication requires a reciprocal relationship between the delivery of messages and recipients namely communicators and communicants. The purpose of Islamic communication is to give good news with the shadow of the multiplication of fahala and the recompense of heaven, giving news of fear of the threat of doom, and the reward of hell. And invite the people to understand and forbid from evil deeds, and remind those who are negligent, and teach and guide those who are ignorant. (Hasbullah, 2018)

Affirmation that communication aims to convey the truth, quoted from Gratitude Kholil from Husain, communication is the process of delivering messages or information from the communicator to the communicant using the principles and methods of communication contained in the Koran and Hadith. In this case, Islamic communication always tries to change the bad treatment of individuals or target audiences to good treatment. Kongkretnya, Islamic communication as described previously, unlike general communication that conveys good or bad information, and try to influence the audience in accordance with the wishes of the communicator who can have a positive or negative tendency.

In a variety of Islamic communication literature, Islamic communication principles are commonly understood. The six principles are as proposed by Rachmat, namely: 1 . Qaulan sadida; 2. Qaulan baligha; 3. Qaulan ma'rufa; 4. Qaulan karma; 5. Qaulan service; 6. Maysura Qaulan. Two of the 6 principles of communication carried out, become the main things that must be considered in the process of political imaging.

Good therapeutic communication from a medical professional such as a doctor or a nurse, is able to provide confidence for patients. In this case, the outward impression or appearance of doctors and paramedics as well as hospitality ranging from a smile full of sincerity, neatness to dress, familiar attitudes, ways of speaking that give an attractive impression, and personal character with wise temperament are needed to become the first drug for patients.

The hospital should be able to provide a complete service that is a service with a comprehensive therapeutic communication phase starting when the patient first comes to the hospital or orientation phase, then at the working phase, which is to unite the communication process with treatment actions and build a supportive atmosphere for the process of change to the completion phase (termination), namely the assessment of the achievement of goals and separation after completion of treatment through medical consultations and therapists provided by doctors and paramedics in an effort to cure the disease.

Communication is an inseparable part of human life because all our steps are always accompanied by communication. The communication in question is Islamic communication, that is, the communication of morality or ethics. Communication with morality al-karimah means communication that originates from the Koran and Hadith (the Sunna of the Prophet). As A. Muis said, Islamic communication has a difference with nonIslamic. The difference is more on the content of the message (content) of communication that must be bound by religious orders, and by itself the element of message content is binding on the communicator element. That is, the communicator must have and uphold the principles of Islamic ethics in delivering messages when talking to patients so that a state of harmony can occur with the patient. In this case doctors, nurses / paramedics.

Doctors and paramedics at the hospital have duties and responsibilities as communicators to realize effective therapeutic communication. Based on the background that has been explained above, then the main problem of research is how to model the 
implementation of Islamic communication in therapeutic communication for healing patients at Adam Malik Hospital in Medan.

\section{Review of Literature}

\subsection{Islamic Communication.}

In Arabic, communication often uses the terms tasawhul and ittishal. For example Prof. Dr. Abdul Karim Bakar when writing about family communication, he gave the title of his book with al-Tawashul al-Usari (Family Communication). The word ittishal is used by Awadh Al-Qarni in his book Hatta la Takuna Kallan (So You Don't Be a Burden for Others). When defining communication, Awad said that communication (ittishal) is to do the best way and use the best means to transfer information, meanings, tastes, and opinions to other parties and influence their opinions and convince them of what we desire to be good with using language and by using others.

The object of study in Islamic communication consists of three parts, namely human communication with God, human communication with himself, and human communication with others. This is in line with the atsar stated by Wahab bin Munabbih narrated by Imam Ahmad bin Hanbal, as follows:

From Wahab bin Munabbih, he said: Written in the Wisdom of David: "It is appropriate for a reasonable person not to be negligent of the four days of his day: a time to be loyal to his Lord, a time to evaluate himself, and a time to gather with his friends who can give advice and show the shortcomings, and time to relax with the lawful and good."

Islamic communication has three main sources, namely:

- Al-Qur'an.

- As-Sunnah.

- The books of the scholars

Islam teaches using gentle communication to anyone. In any environment, the communicator should communicate to the communicant in a gentle way, away from coercion and hostility. By using gentle communication, in addition to a friendly feeling that infiltrated the communicant's heart, he also tried to be a good listener.

There are several ways to cover the truth with communication, namely:

a. Covering up the truth by using abstract, ambiguous words or giving rise to very different interpretations if you disagree with your friend's views, then you immediately call him "no pancasilais". You actually cannot stand being criticized, but it's not good to say it and then you will say, "I appreciate criticism very much, but that criticism must be delivered freely and responsibly". The words "free" and "responsible" are abstract words to avoid criticism. When a preacher finds another Muballig's opinion and his opinion illogical, he will say, "Reason must submit to religion". He actually wanted to say that other people's logic must be subject to his understanding of religion. Intellect and religion are two abstract words. Therefore, advise that we be careful using abstracts.

b. People cover up the truth by creating terms that are given meaning by others. The term is in the form of a euphemism or a reversal of meaning at all. Officials report hunger in their area by saying "cases of malnutrition or" food insecurity ". He is not said to be "arrested", but "secured". Prices are not raised, but are "adjusted".

Establishing a good relationship between health workers and patients is absolutely necessary in an effort to expedite the duties of nurses. There are four actions that must be taken in applying the therapeutic relationship between nurses and patients, namely:

a. The action was initiated by the health team

b. Reaction response from patients 


\section{c. Interaction \\ d. Transaction}

The relationship between health workers and patients is Islamic in character with the relationship with the concept of God and humanity. Basically the relationship is based or sourced from the Koran and the Sunnah. The basics of the relationship are as follows:

a. Fellow Muslims or believers are brothers. This is as Allah has explained in the Koran Q. al-Hujurat: 10 which means: "indeed the believers are brothers, therefore reconcile between your two brothers and fear that Allah will bless you"

b. Do not reproach one another and may not call with bad calls. As Allah has specified in the Koran Q. Al-Hujurat: 11 which means "O you who believe, do not make a people mock other people (because) they may (those who are mocked) are better than those (who make fun of) and not women women (make fun of) other women (because) it may be that women (who are mocked) are better than women (who make fun of) and don't criticize yourself, and don't be cheeky to call with bad titles. The worst part of the call is a bad (call) after faith, and whoever does not repent they are the wrongdoers.

c. Please help with virtue and don't help with sin and hostility. As Allah has specified in Q.S. Al-Maidah: 2 which means "O you who believe, do not violate the Shari'a of Allah, and do not violate the honor of the illegitimate months, do not (disturb) the animals of had-ya and the animals of Qalaaid, and do not (also) disturbing the people who visit Baitullah while they are looking for gifts and relief from their Lord, and if you have completed the pilgrimage then you may hunt. And do not ever (your) hatred for something common because they prevent you from the Grand Mosque, encourage you to persecute (to them). And please help you in (doing) goodness and piety, and don't help in committing sins and transgressions. And fear Allah, verily Allah is severely tortured.

\subsection{Therapeutic Communication in the Medical World}

Communication consists of various forms. One of them is therapeutic communication. Therapeutic communication in the medical world is very important to apply. It is intended to create a relationship between health workers and patients to recognize patient needs and determine action plans and cooperation in meeting patient needs. Therapeutic communication is basically a proportional communication that aims to cure patients with two important components, namely the process and the effects of communication itself. Therapeutic communication is personal communication with a starting point for mutual understanding between patients and medical personnel. Therapeutic communication is interesting for further research. Therefore, in this section, it will be explained further related to therapeutic communication in the medical world.

Carl I.Hoveland, a psychologist at Yale University, stated as follows: "Communication is the process by which an individual transmits stimuli (usualy verbal symbols) to modify the behavior of another individual. "In this definition communication is as a process of stimulating an individual to another individual with meaningful symbols, in the form of words to change behavior.

\subsection{Construction of Implementation of Communication Theory in Therapeutic Communication}

Related to communication theory, there is what is called terpeutik communication. For the community at large, therapeutic communication feels foreign to the ear. Even for some academics who are in the department or faculty of Communication Studies also 
rarely hear it. Therapeutic is a term in the medical world, so in the world of health this language is more familiar to the ear. So, what is therapeutic communication?

Therapeutic is related to therapy in the medical world. In the art of medicine, therapy is needed for efforts to treat chronic, difficult to cure, or special diseases that only require therapy in their treatment. The doctor will first analyze the symptoms of someone's disease, and then determine the right treatment.

Therapeutic communication requires an in-depth approach to the patient to be honest about their illness. The limitation of a docet is only to diagnose someone through existing tools that do not feel the person's actual condition because a tool can make a wrong conclusion. By revealing the symptoms suffered by the patient himself to a doctor can determine more precisely what diseases suffered by a person so that treatment becomes more effective.

To relate it to Lasswell's communication theory, Therapeutic communication requires all factors involved in communication. Who is talking about what, through what media, to whom, and what effect it is, becomes an important indicator in implementing therapeutic communication itself. The model feels complete to see an indication of an illness through communication between doctor and patient. However, this requires the ability of doctors to develop the art of talking while at the same time getting conclusions from each point in the Lasswell communication model.

\section{Reseach Method}

This research is included in the type of field research with a qualitative approach. In this study researchers used data collection obtained by conducting research directly in the field.

It also uses the research library as additional material in this study. The use of library research is strived to help in finding things that have not been answered and complete the results of interviews conducted so that all questions in the focus of the problem can be answered properly. In qualitative research, data and information obtained are then organized and analyzed to get a picture of the object of research.

From the qualitative approach used in this study, the data and information obtained were further organized and analyzed in order to obtain a description (description) of the object of research. Such data and information processing methods are then termed analytical descriptive methods. Regarding this method, Winarno Surachmad explained that, the descriptive method is not limited to the collection of data, but includes: analysis and interpretation of the meaning of the data, comparing similarities and differences in certain phenomena.

\section{Discussion}

\subsection{Islamic Communication Model in Therapeutic Communication Practices in Adam Malik Hospitalls}

Analysis related to the application of Islamic communication values in therapeutic communication practices in H. Adam Malik General Hospital will be presented based on interviews conducted by researchers of several patients who are undergoing treatment at the hospital. In this study, researchers conducted interviews with 4 patients, namely Mrs. Yuliana, Mr Tomblok, Mr Heriadi and Mr Sukri Sembiring. Based on the results of interviews with the four patients, in general, in dealing with patients, the communication applied by doctors at the $\mathrm{H}$. Adam Malik General Hospital has contained the values of 
Islamic communication, although not as a whole. In detail the results of the interview will be presented as follows:

The first interview was conducted with Ms. Yuliana. As an informant, he gave information that doctors at the H. Adam Malik General Hospital always greeted the patient before starting the examination and said excuse me before leaving the patient after the examination. This shows the existence of Islamic values that are applied by doctors at the H. Adam Malik Central General Hospital. The greetings given, such as greetings good morning or evening, depending on the time he examined the patient. This reflects the existence of good manners and contains Islamic values, even though doctors do not give greetings in the form of "Assalamu'alaikum", as it should be applied in Islam. This is because patients and doctors at the H. Adam Malik Central General Hospital are not Muslims as a whole. Even so, the greeting given by the doctor contained good and noble values.

The informant also said that doctors and nurses always introduce themselves first before examining patients. This will obviously make the relationship between doctors and patients warmer, and the examination process will also be smoother and in line with the principles contained in Islamic communication. In addition, the informant said that the attitude displayed by the doctors at the H. Adam Malik Central General Hospital in treating patients was also very good.

This is reflected in the way they speak and the polite and friendly words they use throughout examining patients. It is also in line with Islamic values in Islamic communication, namely qaulan sadida, which is saying in good words and using good language and politeness. In addition, in explaining the patient's condition, the doctor also explained it in detail and clearly and with patience. Such conditions certainly make patients feel very satisfied with the services provided by doctors at the H. Adam Malik General Hospital during the treatment process.

The average doctor in this hospital examines a patient for five minutes. However, this time is used by doctors to treat, examine, explain the patient's condition in great detail, and always listen to patient complaints very carefully. In addition, at the end of the examination, the doctor also did not forget to provide motivation and prayer for the healing of his patients. This clearly has a positive impact on the patient so that he always tries and is motivated to recover quickly from the pain he is suffering from.

The informant also said that the doctors and nurses at H. Adam Malik Central General Hospital always called their patients with polite titles, such as fathers or mothers. They never call their patients bad names. This also reflects the existence of Islamic communication values that are applied in therapeutic communication by doctors and nurses during the treatment process at H. Adam Malik General Hospital.

The second interview was conducted with Mr. Tomblok. In general, based on information obtained from Mr. Tomblok as a patient, doctors at the H. Adam Malik Central General Hospital have also applied the principles of Islamic Communication in therapeutic communication practices at the H. Adam Malik Central General Hospital. The informant provided information that doctors at the H. Adam Malik General Hospital always greeted the patient before starting the examination and said excuse me before leaving the patient after the examination.

The greetings given, such as greetings good morning or evening, depending on the time he examined the patient. This reflects the existence of good manners and contains Islamic values, even though the doctors did not say in the form of "Assalamu 'alaykum", as it should be applied in Islam. This is because patients and doctors at the H. Adam Malik 
Central General Hospital are not Muslims as a whole. Even so, the greeting given by the doctor contained good and noble values.

The informant said that the doctors and nurses did not introduce themselves first before examining patients. This is indeed not in line with the values of Islamic communication that should be applied by doctors and nurses in examining patients. Even so, doctors still provide good service to patients. The attitude shown by the doctors at the H. Adam Malik Central General Hospital in dealing with patients was also very good. This is reflected in the way they speak and the polite and friendly words they use throughout examining patients. It is also in line with Islamic values in Islamic communication, namely qaulan sadida, which is saying in good words and using good language and politeness.

In addition, in explaining the patient's condition, the doctor also explained it in detail and clearly and with patience. Such conditions certainly make patients feel very satisfied with the services provided by doctors at the H. Adam Malik General Hospital during the treatment process. The average doctor in this hospital examines a patient for five minutes. However, this time is used by doctors to treat, examine, explain the patient's condition in great detail, and always listen to patient complaints very carefully.

In addition, at the end of the examination, the doctor also did not forget to provide motivation and prayer for the healing of his patients. This clearly has a positive impact on patients to always try and be motivated to recover quickly from the pain he is suffering and is also in line with the principles of Islamic communication that should be applied. The informant also said that the doctors and nurses at H. Adam Malik General Hospital always called their patients with polite titles, such as fathers or mothers. They never call their patients bad names. This also reflects the existence of Islamic communication values that are applied in therapeutic communication by doctors and nurses during the treatment process at H. Adam Malik General Hospital.

The third interview was conducted with Mr. Heriadi. In general, based on information obtained from Mr. Heriadi as a patient, doctors at the H. Adam Malik Central General Hospital have also applied the principles of Islamic Communication in Therapeutic communication practices. The informant provided information that doctors at the H. Adam Malik General Hospital always greeted the patient before starting the examination and said excuse me before leaving the patient after the examination.

The greetings given, such as greetings good morning or evening, depending on the time he examined the patient. This reflects the existence of good manners and contains Islamic values, even though doctors do not give greetings in the form of "Assalamu'alaikum", as it should be applied in Islam. This is because patients and doctors at the H. Adam Malik Central General Hospital are not Muslims as a whole. Even so, the greeting given by the doctor contained good and noble values.

The informant said that doctors and nurses did not introduce themselves first before examining patients. This is indeed not in line with the values of Islamic communication that should be applied by doctors and nurses in examining patients. Even so, doctors still provide good service to patients. The informant conveyed information that the attitude displayed by the doctors at the H. Adam Malik Central General Hospital in treating patients was also very good. This is reflected in the way they speak and the polite and friendly words they use throughout examining patients.

It is also in line with Islamic values in Islamic communication, namely qaulan sadida, which is saying in good words and using good language and politeness. In addition, in explaining the patient's condition, the doctor also explained it in detail and clearly and with patience. Such conditions certainly make patients feel very satisfied with the services provided by doctors at the $\mathrm{H}$. Adam Malik General Hospital during the treatment process. 
The average doctor in this hospital examines a patient for four minutes. However, this time is used by doctors to treat, examine, explain the patient's condition in great detail, and always listen to patient complaints very carefully.

In addition, at the end of the examination, the doctor also did not forget to provide motivation and prayer for the healing of his patients. This clearly has a positive impact on patients to always try and be motivated to recover quickly from the pain he is suffering and is also in line with the principles of Islamic communication that should be applied. In addition, the informant also conveyed information that the doctors and nurses at the $\mathrm{H}$. Adam Malik Central General Hospital always called their patients with polite titles, such as fathers or mothers. They never call their patients bad names. This also reflects the existence of Islamic communication values that are applied in therapeutic communication by doctors and nurses during the treatment process at $\mathrm{H}$. Adam Malik General Hospital.

The fourth interview was conducted with Mr. Sukri Sembiring. In general, based on information obtained from Mr. Sukri Sembiring as a patient, doctors at the H. Adam Malik Central General Hospital have also applied the principles of Islamic Communication in Therapeutic communication practices. Infomran provides information that doctors at the $\mathrm{H}$. Adam Malik General Hospital always greet the patient before starting the examination and say excuse me before leaving the patient after the examination.

The greetings given are more traditionalist greetings, such as "Mejuah-juah". This reflects the existence of good manners and contains Islamic values, even though doctors do not give greetings in the form of "Assalamualaikum", as it should be applied in Islam. This is because patients and doctors at the H. Adam Malik Central General Hospital are not Muslims as a whole. Even so, the greeting given by the doctor contained good and noble values.

The informant said that doctors and nurses did not introduce themselves first before examining patients. This is indeed not in line with the values of Islamic communication that should be applied by doctors and nurses in examining patients. Even so, doctors still provide good service to patients. The attitude shown by the doctors at the H. Adam Malik Central General Hospital in dealing with patients was also very good.

This is reflected in the way they speak and the polite and friendly words they use throughout examining patients. It is also in line with Islamic values in Islamic communication, namely qaulan sadida, which is saying in good words and using good language and politeness. In addition, in explaining the patient's condition, the doctor also explained it in detail and clearly and with patience. Such conditions certainly make patients feel very satisfied with the services provided by doctors at the H. Adam Malik General Hospital during the treatment process.

The average doctor in this hospital examines patients for five to six minutes. However, this time is used by doctors to treat, examine, explain the patient's condition in great detail, and always listen to patient complaints very carefully. In addition, at the end of the examination, the doctor also did not forget to provide motivation and prayer for the healing of his patients. This clearly has a positive impact on patients to always try and be motivated to recover quickly from the pain he is suffering and is also in line with the principles of Islamic communication that should be applied.

In addition, the doctors and nurses at $\mathrm{H}$. Adam Malik General Hospital always call their patients with polite titles, such as fathers or mothers. They never call their patients bad names. This also reflects the existence of Islamic communication values that are applied in therapeutic communication by doctors and nurses during the treatment process at H. Adam Malik Central Hospital. 
Good advice and pray for each other is also an implementation of the values of Islamic communication in therapeutic communication that is established in the hospital. Adam Malik. The medical staff always provide advice in a way and good delivery to their patients, and always pray for patients and provide motivation to patients to get well soon. This clearly has a positive impact on patients and their families.

\section{Conclusion}

The model of implementation of Islamic communication in therapeutic communication for healing patients at Adam Malik Hospital in Medan is Interpersonal Communication which is considered the most effective because of its dialogical nature in the form of conversation. From this communication the medical staff can find out changing the attitudes, opinions and behavior of the patient so that therapeutic communication is expected in the patient's healing process to be effective. In addition, the implementation model of Islamic communication in therapeutic communication of this study produced a marker communication model, namely communication carried out on the basis of the awareness of the medical team, namely nurses and doctors. This model of Islamic communication is not formally implemented, but substantially has similarities with the values of Islamic communication.

\section{References}

Abdurrahman bin Nashir bin Abdullah al-Sa'di. Tafsir al-Karim al-Rahm fi Tafsir Kalam al-Mannan (Mu'assasah al-Risalah, 1420 H-2000 M.)

Abu al-Qasim al-Husain bin Muhammad. Al-Mufradat fi Gharib al-Quran. Dimasyq: Dar al-Qalam, 1412.

Ali bin Muhammad bin Ali al-Zain al-Syarif Al-Jurjani, Al-Ta'rifat. Beirut: Dar al-Kutub al-'Ilmiyyah, 1403-1983.

Amir, Mafri. (1999). Etika Komunikasi Massa Dalam Pandangan Islam. Jakarta: Logos.

Dinas Kesehatan Kota Medan, Provinsi Sumatera Utara.

Effendy, Onong Uchjana. (2000).Ilmu Komunikasi Teori dan Filsafat Komunikasi Bandung, PT. Cipta Aditya Bakti.

Fairus Ali Abdad. (2012). "Tingkat Pengetahuan Perawat Tentang Komunikasi Terapeutik di Unit Rawat Inap Umum Rumah Sakit Dr. H. Marzoeki Mahdi Bogor”, Fakultas Ilmu Keperawatan Universitas Indonesia, Jakarta.

Hasbullah. (2018). Communication Pattern of Wilayatul Hisbah, Lhokseumawe City in Implementing Amar Makruf Nahi Mungkar. Budapest International Research and Critics Institute-Journal (BIRCI-Journal). P. 194-205.

Huberman, Matthew B. Miles and A. Michael. (1992). Analisis Data Kualitatif. Terj. Tjetjep Rohendi Rohidi. Jakarta: UI Press.

Hussain. (1990). Dua Puluh Lima Soal Jawab, Mengenai Komunikasi Islam. Pengarah, Pusat Pengembangan dan Pendidikan Lanjutan, Universiti Pertanian Malaysia. Serdang Selangor, Darul Ehsan.

Ibnu Mandzur, Lisan al-'Arab. Beirut: Dar Shadir, 1412-1992. juz 13.

Indra, \& Gunarsih. (2002).Pengaruh Kualitas Pelayanan Terhadap Kepuasan Nasabah Kredit Perorangan Dan Kelompok: Studi Kasus Pada PD BPR Bank Pasar Kabupaten Karanganyar". Jurnal Manajemen. Vol 2 tahun.

Kozier. (2004). Fundamentals of Nursing; Concepts, Process and Practice, seventh edition. United States: Pearson Prentice Hall. 
Kumpulan makalah, Pembahasan dan Resolusi pada Congress of Muslim Librarians and Information Specialists di University Utara Malaysia, Kedah Malaysia, 20-22 Oktober 1986.

Muchyiddin, Ase S. (1998). Pendekatan Sumber-sumber Informasi Dalam Proses Komunikasi dan Diseminasi Informasi. Bandung: PT Remaja Rosdakarya,.

Nursalam, M. (2002). Manajemen Keperawatan: Aplikasi dalam Praktik Keperawatan Profesional. Jakarta: Salemba Medika.

Ovretveit, John. (1992). Health Service Quality: An Indroduction to quality methods for Health Service. Cambridge: Cataloguing in Publication Data.

Ritonga, Muhamad Husni. (2008). Eksistensi Ilmu Komunikasi Islam. Bandung: Citapustaka.

Saefullah, Ujang. (2007). Kapita Selekta Komunikasi Pendekatan Budaya dan Agama. Bandung, Simbiosa Rekatama Media.

Setianti, Yanti. (2007). Komunikasi Terapeutik antara Perawat dan Pasien, Makalah Ilmiah Fakultas Ilmu Komunikasi. Universitas Padjajaran Jatinagor.

Siregar, Ashadi. (2008).Etika Komunikasi. Yogyakarta: Penerbit Pustaka.

Sugiyono. (2010). Metode Penelitian Kuantitatif, Kualitatif dan R\&D. Bandung: Alfabeta.

Wursanto. (1991). Etika Komunikasi Kantor. Yogyakarta: Kanisius.

Zainuddin Abu Abdillah Muhamm bin Abi Bakar bin Abdul Qadir al-Hanafi al-Razi. Muhktar al-Shihah. Beirut: Al-Maktabah al-'Ashriyyah, 1420-1999.

Zamroni, Mohammad. (2009). Filsafat Komunikasi:Pengantar Ontologis, Epistimologis, Aksiologis. Yogyakarta: Graha Ilmu.

Wawancara dengan Ibu Yuliana di Rumah Sakit Umum Provinsi H. Adam malik Medan 